\title{
Unveiling the neurobiology of learning and memory: the lifetime accomplishments of Ivan Izquierdo (1937-2021)
}

\author{
Flavio Kapczinski, ${ }^{1,2}$ (iD Antonio E. Nardi, ${ }^{3}$ iD João Quevedo ${ }^{4,5,6,7}$ (iD \\ ${ }^{1}$ Departamento de Psiquiatria, Universidade Federal do Rio Grande do Sul (UFRGS), Porto Alegre, RS, Brazil. ${ }^{2}$ Mood Disorders Program, \\ Department of Psychiatry and Behavioural Neurosciences, McMaster University, Hamilton, Ontario, Canada. ${ }^{3}$ Instituto de Psiquiatria, \\ Universidade Federal do Rio de Janeiro (URFJ), Rio de Janeiro, RJ, Brazil. ${ }^{4}$ Translational Psychiatry Program, Faillace Department of \\ Psychiatry and Behavioral Sciences, McGovern Medical School, The University of Texas Health Science Center at Houston (UTHealth), \\ Houston, TX, USA. ${ }^{5}$ Center of Excellence on Mood Disorders, Faillace Department of Psychiatry and Behavioral Sciences, McGovern Medical \\ School, UTHealth, Houston, TX, USA. ${ }^{6}$ Neuroscience Graduate Program, The University of Texas MD Anderson Cancer Center, Graduate \\ School of Biomedical Sciences, UTHealth, Houston, TX, USA. ${ }^{7}$ Laboratório de Psiquiatria Translacional, Programa de Pós-Graduação em \\ Ciências da Saúde, Universidade do Extremo Sul Catarinense (UNESC), Criciúma, SC, Brazil.
}

A giant is gone. The enchanting Ivan Izquierdo - scientist, humanist, and mentor - died on February 9th, 2021, at the age of 84 . His students called him "The Professor," almost as if he was the only one deserving of such title at the Universidade Federal do Rio Grande do Sul (UFRGS), where he taught. This respect and admiration were linked to his deep understanding of neuroscience and, most importantly, his humanistic traits.

In one of thousands of examples of how he cared for each of us, many years ago, a former student (currently a university professor) became pregnant in the middle of her $\mathrm{PhD}$ course and was afraid to approach Izquierdo to tell him the news that could jeopardize her work. Having overcome her initial reluctance and reached out to him, she was surprised by his attitude: as always, he was warm and kind, offered support, and adapted her tasks to the restrictions of pregnancy. Izquierdo left very deep impressions on many people. That was in part due to his scientific knowledge, but also due to his personable demeanor.

All over Brazil, Argentina as well as many other places worldwide, the impressions left by Izquierdo on influential scientists and clinicians had, perhaps, a unifying theme: science is made with people, and for people. His true and uncompromising personal ethics were always intertwined with his passion for culture and the humanities.

In his youth, Izquierdo was intrigued by the concept of memory, particularly after he learned about "Funes: The Memorious,"1 a short story by Jorge Luis Borges published in his book Ficciones. The fictional Funes was a young mnemonist, unable to forget. He could reconstruct even the shape of clouds he had watched go by in his childhood. However, this amazing ability meant that all Funes could do all day long was remember, leaving him incapable of any abstraction. That was a first Eureka

Correspondence: Antonio E. Nardi, Laboratório de Pânico e Respiração, Instituto de Psiquiatria, Universidade Federal do Rio de Janeiro, Rua Visconde de Pirajá, 407/702, CEP 22410-003, Rio de Janeiro, RJ, Brazil.

E-mail: antonioenardi@gmail.com

Submitted Feb 11 2021, accepted Mar 08 2021, Epub Apr 122021.

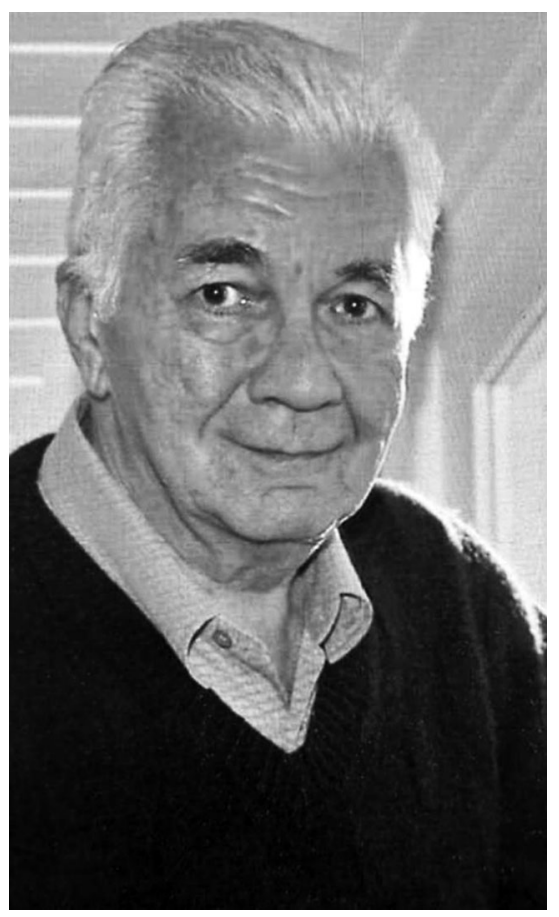

Ivan Antonio Izquierdo (1937-2021)

moment for Izquierdo: forgetting seemed just as important as remembering.

Izquierdo would go on to become a neuroscientist and help lay the foundations for the molecular basis of memory. Izquierdo's experiments showed that, after experiences, specific regions of the brain would influence the consolidation of memories, and such regions would change over time. His findings have influenced clinical

How to cite this article: Kapczinski F, Nardi AE, Quevedo J. Unveiling the neurobiology of learning and memory: the lifetime accomplishments of Ivan Izquierdo (1937-2021). Braz J Psychiatry. 2021;43:353-354. http://dx.doi.org/10.1590/1516-4446-2021-1805 
therapies for posttraumatic stress disorder and Alzheimer's disease.

Ivan Antonio Izquierdo was born in 1937 in Buenos Aires, Argentina, where he attended school, occasionally spending time at his grandfather's farm. In his teens, conversations with his uncle, a physician, lead him to consider a career in science. After all, it was the family business: Izquierdo's father was a pharmacologist, and his mother had studied pharmacy as well.

Izquierdo completed his medical training at Universidad de Buenos Aires in 1955, and in 1959, decided to pursue a doctorate in pharmacology. At that time, he published his first international paper. ${ }^{2}$ As he told his students many years later, he was unimpressed by the proofs of his paper, but was happy to know that the janitor at the Universidad offered to buy him a drink when he heard about the publication. At that time, while working in his father's lab, Izquierdo began to study memory in animal models, and subsequently joined the laboratory of famed neuroscientist Eduardo De Robertis.

After working with De Robertis, Izquierdo spent time at the University of California, Los Angeles (UCLA). There he worked with John Green, who introduced Izquierdo to the intracellular compartment and its mechanisms. At that time, Izquierdo implanted microelectrodes in the hippocampus recording electric signals. Izquierdo and Green were doing research on "postsynaptic potentiation," a process they postulated would be found crucial to learning and memory. Indeed, 9 years later, Tim Bliss discovered a similar process and called it "long-term potentiation," now considered a cornerstone of memory formation.

By 1964, Izquierdo had returned to Argentina and, by 1966, become a full professor at Universidad de Córdoba. $\mathrm{He}$ first continued the work started at Green's laboratory, but at that time in Argentina resources for research were scarce and Izquierdo could not keep up with what scientists were doing elsewhere. He felt frustrated, and shifted back to behavioral neurochemistry. That opened the avenues whereby Izquierdo and other scientists discovered the mechanisms that modulate memories.

In 1973, when the political situation in Argentina became untenable due to a military coup, he moved to Brazil, settling with his Brazilian wife and children in Porto Alegre. There, he set up his laboratory at UFRGS and became a Brazilian citizen. In Brazil, he received more than 60 awards for his work, including fellowship of the Brazilian Academy of Sciences in 1977, two gold medals in 1996 and 2007, and the Conrado Wessel Award - the country's major scientific prize - in 2008. His work was recognized in many Countries and in 2010 he was elected a member of the National Academy of Sciences in the United States.
In 1988, Izquierdo began a very prolific collaboration with Jorge H. Medina at the Universidad de Buenos Aires, and their joint body of work became the most cited in Latin America for many decades. That includes Izquierdo's most important paper, published in 1998, when he and Medina showed that there was not only "one" short-term memory pathway leading to long-term memory ${ }^{3}$; in fact, both processes occurred concomitantly.

In 2004, Izquierdo moved across town from UFRGS to the Memory Center at the Pontifícia Universidade Católica de Porto Alegre, where he would work until his recent death. Of note, Izquierdo had many interests apart from science and published about 60 fictional short stories, usually in the noir genre, featuring characters from the time of World War II or the Buenos Aires of his childhood. His discoveries influenced various fields of modern psychiatry, shedding light on the mechanisms of memory, extinction, and consolidation. In terms of education in psychiatry, in the year 2000, Izquierdo helped two early career mentees, Joao Quevedo and Flavio Kapczinski, edit the book Bases biológicas dos transtornos psiquiátricos (Biological bases of psychiatric disorders) ${ }^{4}$ which has been widely used to educate psychiatrists about neuroscience in Brazil.

Apart from being called "The Professor," many students, mentees, and colleagues called him "Mestre" - which means mentor, in Portuguese. Persistent, perfectionist, and sometimes stubborn, Izquierdo was a giant in science and in the art of navigating mentees to develop their own successful paths. "The Professor," "The Master," his writings, and his own example will always inhabit the space treasured by Borges in his literature: memories.

A true "Professor" never dies, just gives no more lectures.

Dear Professor, thank you for your mentorship and friendship.

\section{Disclosure}

The authors report no conflicts of interest.

\section{References}

1 Borges JL. Funes el memorioso. In: Borges JL. Ficciones. Buenos Aires: Editorial Sur; 1942.

2 Mancini RE, Izquierdo I, Kirschbaum P. [Effects of testosterone on the incorporation of $\mathrm{S} 35$ by the mucopolysaccharides of the connective tissue of the cock's comb]. Rev Soc Argent Biol. 1957;33: 262-71.

3 Izquierdo I, Barros DM, Mello e Sousa TM, de Souza MM, Izquierdo LA, Medina JH. Mechanisms for memory types differ. Nature. 1998; 393:635-6.

4 Kapczinski F, Quevedo J, Izquierdo I. Bases biológicas dos transtornos psiquiátricos. Porto Alegre: Artmed; 2000. 